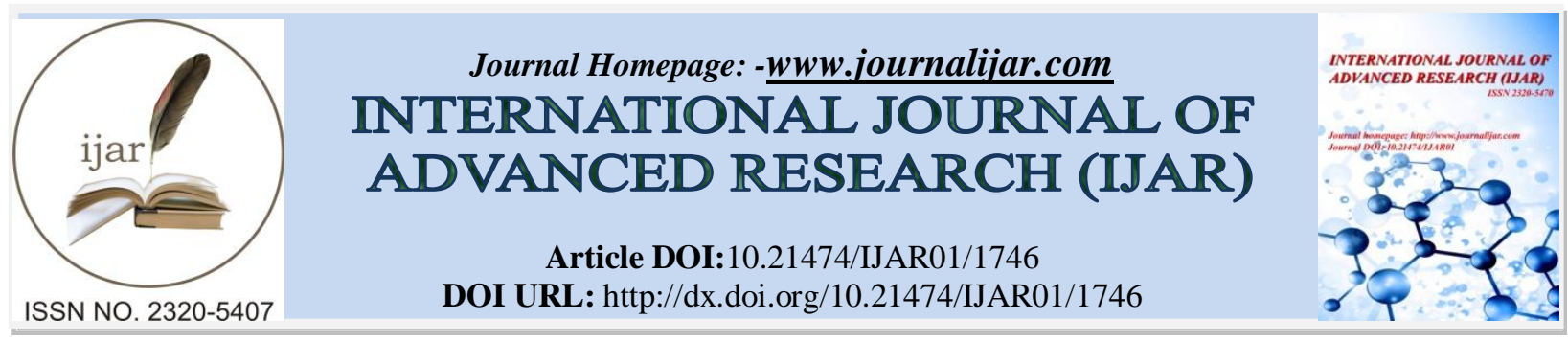

RESEARCH ARTICLE

\title{
INVESTIGATE THE INTERACTION BETWEEN P53 AND RETINOBLASTOMA DURING HSV-1 INFECTION.
} Khalid Alghamdi, Abdullah Almuqrin, Mohammed Alghamdi, Rakan Khawaji, Abdulmahsen Alsalman and
Suliman Alaqeel.

\section{Manuscript Info}

Manuscript History

Received: 12 July 2016

Final Accepted: 22 August 2016

Published: September 2016

Key words:-

\section{Abstract}

\section{Introduction:-}

Cancer refers to an uncontrolled abnormal growth of cells which is a major cause of mortality over the globe [1]. According to GLOBOCAN estimate, 14.1 and 8.2 million new cancers cases and deaths due to cancer respectively occurred in 2012 globally [2]. For the way of explanation, cancer is increasing worldwide, contributing to an enormous burden on society through morbidity, mortality and economic loss, even in the developed countries [2]. However, early diagnosis and in-time proper management with chemotherapy, radiotherapy or surgery can reduce this burden.

Retinoblastoma is a rapidly growing the most common primary intra-ocular malignancy, usually affecting children below 5 [3]. It develops from the cells having mutant copies of RB1 gene which encodes for a tumor suppressor protein called retinoblastoma protein $(\mathrm{pRb})$ [4]. It accounts for 10-15 percent cancers occurring in the first year of life, and is diagnosed in about 8000 children each year globally [5,6]. Management options for Rb include local ophthalmic treatment, systemic chemotherapy, readiotherapy and surgery [7]. Early detection of intra-ocular tumors offer $95 \%$ cure, but extra-ocular expansion increases the mortality [8].

Tumorigenesis sequentially affects the regulatory biological processes which help cell proliferation and their survival. In general, most of the human tumors affect Rb and p53 regulatory pathways [9]. Previously, it was suggested that tumorigenesis of retinoblastoma bypasses or does not involve sequential lesions in p53 pathway [10]. On the contrary, Laurie et al. [9] has challenged this notion of bypassing p53 pathway in retinoblastoma.

Belonging to herpesviridae family, herpes simplex virus (type 1 and 2) is an enveloped double stranded DNA virus, found all over the world causing oral lesions (cold sores) or genital sores [11]. Herpes simplex virus type 1 (HSV-1) is predominantly found in orofacial lesions and is transmitted through mucosal membranes and non-intact skin [12]. It has been suggested that HSV-1 has ability to control the role of p53 in a balance and to cause cell death through HSV-dependent apoptosis (HDAP) to which oncogenic pathway is susceptible [13]. Being neurotropic DNA virus, HSV-1 has been reported to be oncolytic as it can work as a vector for cancer therapeutic genes [14]. It has been studied that HSV-1 modulates Rb gene and this very notion can affect the viral replication, pathogenesis, and 
oncogenesis [15]. Therefore, as HSV-1 modifies Rb and p53 pathways, it may play a positive or negative role in the tnumorigeneis of retinoblastoma.

Because both $\mathrm{p} 53$ and $\mathrm{Rb}$ are tumor suppressor proteins, in this experimental study we aim to investigate if there is an interaction between $\mathrm{p} 35$ and Rb proteins together during HSV-1 infection.

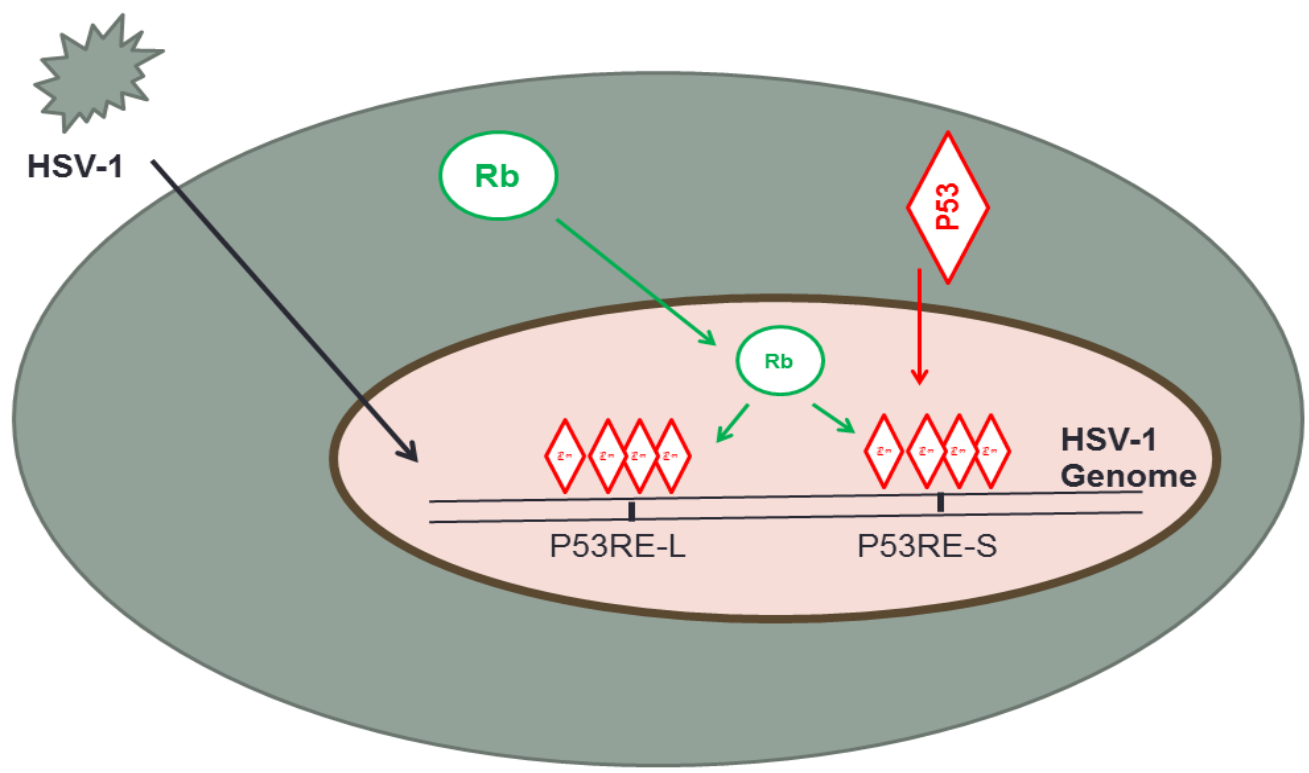

\section{Material and methods:-}

In order to test our hypothesis if these two proteins may interact together, we performed the following experiments using the protocols form ABCAM website [16]:

Transfection experiment. The purpose of this experiment to prepare HEK293 lysates for co-immunoprecipitation.

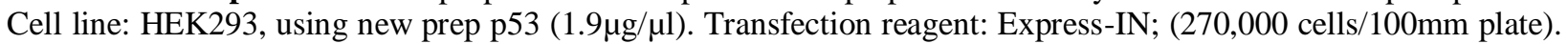
Transfection Protocol for per $100 \mathrm{~mm}$ plate: 1 . Add to the first tube $5 \mu \mathrm{g}$ plasmid plus $200 \mu \mathrm{l}$ MEM serum free

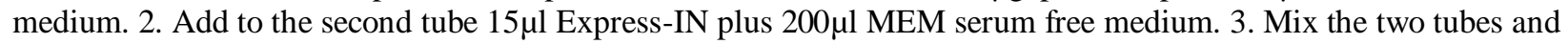
incubates for $20 \mathrm{~min}$ at room temperature. 4 . Transfect $400 \mu \mathrm{l}$ mixture to each $100 \mathrm{~mm}$ plate.

BCA protein assay. It is divided into three steps. First, preparing standers and it include the following protocol: label six eppendorf tubes $(0 \mu \mathrm{g} / \mu \mathrm{l}, 0.125 \mu \mathrm{g} / \mu \mathrm{l}, 0.250 \mu \mathrm{g} / \mu \mathrm{l}, 0.500 \mu \mathrm{g} / \mu \mathrm{l}, 1.00 \mu \mathrm{g} / \mu \mathrm{l}$ and $2.00 \mu \mathrm{g} / \mu \mathrm{l})$, pipette $1 \mathrm{ml}$ of nanopure $\mathrm{H} 2 \mathrm{O}$ into the tube labeled $0 \mu \mathrm{g} / \mu \mathrm{l}$, pipette $100 \mu \mathrm{l}$ of BSA stock into tube labeled $2.00 \mu \mathrm{g} / \mu \mathrm{l}$, pipette $50 \mu \mathrm{l}$ of nanopure $\mathrm{H} 2 \mathrm{O}$ into tubes labeled $0.125 \mu \mathrm{g} / \mu \mathrm{l}, 0.250 \mu \mathrm{g} / \mu \mathrm{l}, 0.500 \mu \mathrm{g} / \mu \mathrm{l}$ and $1.00 \mu \mathrm{g} / \mu \mathrm{l}$, pipette $50 \mu \mathrm{l}$ of BSA from the $2.00 \mu \mathrm{g} / \mu \mathrm{l}$ tube into the $1.00 \mu \mathrm{g} / \mu \mathrm{l}$ tube and vortex, pipette $50 \mu \mathrm{l}$ of the combined BSA and $\mathrm{dH} 2 \mathrm{O}$ from the $1.00 \mu \mathrm{g} / \mu \mathrm{l}$ tube into the $0.500 \mu \mathrm{g} / \mu \mathrm{l}$ and vortex, pipette $50 \mu \mathrm{l}$ of the combined BSA and $\mathrm{dH} 2 \mathrm{O}$ from $0.500 \mu \mathrm{g} / \mu \mathrm{l}$ tube into the $0.250 \mu \mathrm{g} / \mu \mathrm{l}$ and vortex, pipette $50 \mu \mathrm{l}$ of the combined BSA and $\mathrm{dH} 2 \mathrm{O}$ from the $0.250 \mu \mathrm{g} / \mu \mathrm{l}$ tube into the $0.125 \mu \mathrm{g} / \mu \mathrm{l}$ and vortex. Second, preparing 96-well plate and it include the following protocol:use 96-well plate cover to mark which wells each sample and standards will be placed, mark standards in either duplicate or triplicate to insure precision, pipette $10 \mu \mathrm{l}$ of blank/standards into designated well, the first row of standards should be just water and the prepared samples in the following rows, pipette $9 \mu \mathrm{l}$ of $\mathrm{dH} 2 \mathrm{O}$ into the rest of the wells which will hold sample, pipette $1 \mu 1$ of sample into designated wells for sample used. Third, preparing BCA reagentsand it include the following protocol: calculate amount needed for reagent A then add to falcon tube as following equation (\# wells +1$) \times 200=\ldots \quad \mu 1$ reagent $A$, calculate amount needed for reagent $B$ the add to the same falcon tube as following equation $(\ldots \mu$ l reagent $A) \div 50=\ldots \mu l$ reagent $B$, vortex solution, each well of the plate will receive $200 \mu \mathrm{l}$ of the BCA reagent, add $200 \mu \mathrm{l}$ of $\mathrm{A} / \mathrm{B}$ reagent to all wells, incubate at $37^{\circ} \mathrm{C}$ for 15 minutes. After these three steps we used Tecan Safari2 for reading and it has own protocol. 
Co-immunoprecipitation.Co-immunoprecipitation (Co-IP) is a popular technique for the analysis of protein interaction. The procedure includes: 1) An antibody specific to the protein of interest is added to a cell lysate. 2) The antibody-protein complex is then precipitated usually using protein-G or protein-A sepharose which binds most antibodies. If there are any protein/molecules that bind to the first protein, they will also be precipitated. 3) Coprecipitated protein can then be identified by Western blot analysis or by sequencing a purified protein band.After

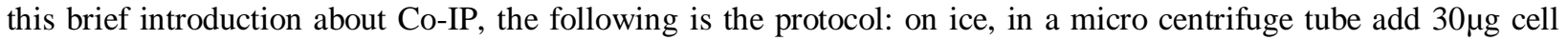
lysate plus $5 \mu \mathrm{l}$ ap53 antibody (DO-1), incubate the sample with antibody $1-12 \mathrm{hr}$ (overnight) at $4^{\circ} \mathrm{C}$ and under gentle rotation, meanwhile prepare the Sepharose beads (A/G-coupled Sepharose beads), mix the slurry well and add $70-100 \mu l$ of the beads to each sample and always keep samples on ice, beads will tend to stick to the sides of the tip so try to minimize the movement in the pipette and use a tip cut $5 \mathrm{~mm}$ from the top, incubate the lysate beads mixture at $4^{\circ} \mathrm{C}$ under gentle rotation for $2 \mathrm{hr}$, the lysate-beads/antibody incubation time over centrifuge the tube, remove the supernatant from the beads and discard, the complex of interest should now be specifically bound to the antibody coating the beads, wash the beads with washing buffer or lysis buffer 3 timesto remove non-specific binding, for each tube wash and mix the beads gently with wash buffer, centrifuge at $4^{\circ} \mathrm{C}$ and remove the supernatant which can be discarded, ensure to carefully remove as much wash buffer as possible from the beads, the complex is now ready for elution from beads, following steps regarding SDS buffer elution, in SDS elution the Ag-Ab comlex is eluted from the beads by heating and boiling samples, in loading buffer with denaturant SDS, this method is advantageous because the extraction method is highly efficient and the resulting sample is more concentrated, it include 4 steps as following, elute $50 \mu \mathrm{l}$ of beads by heating in $50 \mu \mathrm{l}$ of $2 \times \mathrm{SDS}$ without DTT for 10 minutes at $50^{\circ} \mathrm{C}$, pellet beads transfer supplement to a new tube and add DDT at $100 \mathrm{mM}$, add $50 \mu 12 \times$ SDS buffer with DDT to pelleted beads, boil the elution samples for 5 minutes and analyze content of the sample by western blot.

Western blotting. Western Blotting, Western blot or immunoblotting (Western blotting was dubbed because it is similar to Southern blotting which was invented by and named after the inventor E. M. Southern) allows investigators to determine, with a specific primary antibody, the relative amounts of the protein present in different samples. Briefly, 1) Samples are prepared from tissues or cells that are homogenized in a buffer that protects the protein of interest from degradation; 2) The sample is separated using SDS-PAGE and then transferred to a membrane for detection; 3) The membrane is incubated with a generic protein (such as milk proteins) to bind to any remaining sticky places on the membrane. A primary antibody is then added to the solution which is able to bind to its specific protein; 4) A secondary antibody-enzyme conjugate, which recognizes the primary antibody is added to find locations where the primary antibody bound. After this brief introduction about western blot, the following is the protocol: set up a std mini gel with with 7.5\% SDS/PAGE plus adding double dose of Temed $15 \mu$ plus leveling by isopropanol, load $10 \mu \mathrm{g}$ extract protein plus $7 \mu \mathrm{l}$ Bio-Rad pre-stained protein marker, run mini gel at 120 Volt on Bio-Rad power PAC 200 supply, transfer blot by a Bio-Rad box at constant mA at $250 \mathrm{~mA}$ (9Volt) for 90 minutes2hrs using Bio-Rad power PAC 3000 supply, blocking membrane by TBST 5\% milk for 1hr, set up the glass plate wrapped by parafilm and add p53-primary $\mathrm{Ab} 0.5 \mu \mathrm{l}$ in a big Tip Box and incubate in a $4^{\circ} \mathrm{C}$ refrigerator not in cold room, next day, washing membrane with TBST for $1 \mathrm{hr}$, change a new parafilm for glass plate and incubate with $2^{\text {nd }}$ $\mathrm{Ab} 0.2 \mu \mathrm{l}$ at room temp for $1 \mathrm{hr}$, washing membrane for $1 \mathrm{hr}$, turn on $\mathrm{x}$-ray film machine, detecting $\mathrm{p} 53$ by mix $1 \mathrm{ml}$ sol'n A and $25 \mu \mathrm{l}$ sol'n B in a microtube and at membrane on the plastic wrap and incubate for 5 minutes, dry and transfer membrane to cassette and expose to different time (1", $2 "$ or $5 " \ldots)$.

Membrane stripping and re-probing. Stripping is the term used to describe the removal of primary and secondary antibodies from a Western blot membrane. Stripping is useful when one wants to investigate more than one protein on the same blot, for instance a protein of interest and a loading control. When probing for multiple targets, stripping and re-probing a single membrane instead of running and blotting multiple gels have the advantage of saving samples, materials, and time. After this brief introduction about membrane stripping and re-probing, the following is the protocol: add $280 \mu \mathrm{l}$ of $\beta$-mercaptoethanol per $40 \mathrm{ml}$ of stripping buffer to a final concentration of $100 \mathrm{mM}$, wash membrane in TBST ( $1 \times 5$ minutes), incubate membrane in stripping buffer for 30 minutes at $50-60^{\circ} \mathrm{C}$, wash in TBST (3-4×10 minutes), block membrane for $1 \mathrm{hr}$ of $\mathrm{O} / \mathrm{N}$ in $5 \%$ blocking milk, follow normal protocol for developing western blots.

\section{Results:- \\ Result \#1:-}

Co-IP exp was carried out with lysates prepared from Vero (exp\#1) and HEK293 (exp\#2) cell lines. The $1^{\text {st }}$ group was mock; the $2^{\text {nd }}$ group was HEK293 transfected with p53 plasmid and $3^{\text {rd }}$ group was also infected with HSV-1 with $\mathrm{MOI}=5$. 


\section{Western blotting using anti-p53 antibody}

Lane1 is a purified p53 protein used for positive control (Allow us to know the exact p53 protein migration position in the polyamide gel and we bought it from BD company). Lane2 is a p53 transfection input used for another positive control (Showed our p53-transfected HEK293 cells containing p53 in the cell lysate). Lane3 is coimmunoprecipitated complex from Mock group. Lane4 is co-immunoprecipitated complex from p53 transfection group. Lane5 is co-immunoprecipitated complex from p53 transfection and HSV-1 infection group.

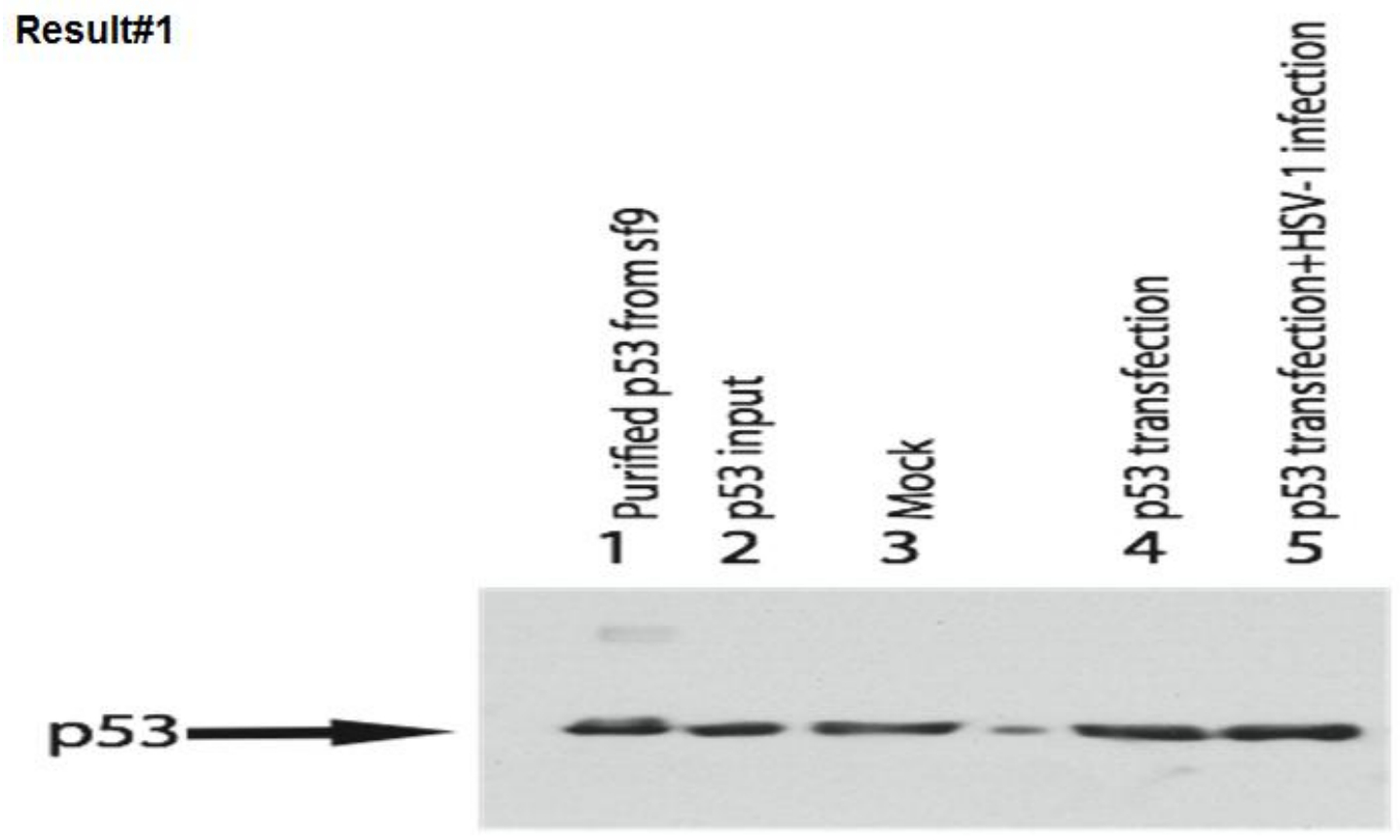

\section{Result\#2:-}

We stripped the first WB membrane, and Re-probing with Rb antibody.

\section{Result\#2}
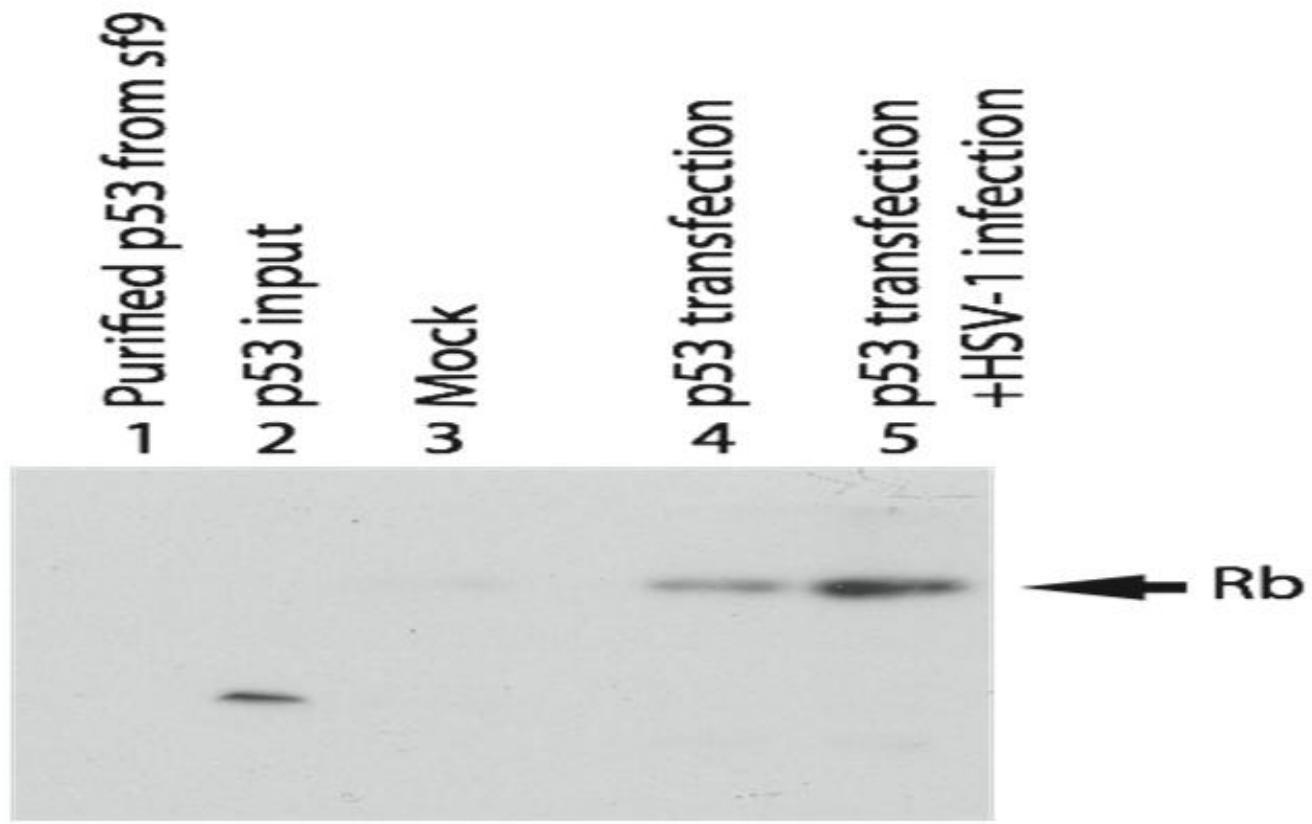


\section{Discussion:-}

Regarding result\#1:-

The p53 band was detectable. And p53 band is slightly increased in lane4 and lane5. Which means HSV-1 infection enhanced the interaction. And this result confirms that there is interaction over the response element of the p53.

\section{Regarding result\#2:-}

The $\mathrm{Rb}$ protein was detectable in lane 4 and lane5. Which indicate that there is interaction between $\mathrm{p} 53$ and $\mathrm{Rb}$ (Lane4). And we can see that after the HSV-1 infection the interaction between p53 and Rb is enhanced (Lane5). And this result support that there is interaction between p53 and Rb proteins during HSV-1 infection.

\section{Conclusion:-}

The main two conclusions are: (1) Our Co-IP result suggests that p53 interacts with Rb in HEK293 cells. (2) P53-Rb interaction enhanced by HSV-1 infection in HEK293 cells.In order to prevent the carcinogenesis of HSV-1 we recommend to understanding the nature of the interactions between 553 and $\mathrm{Rb}$ proteins during HSV-1 infection by further studies.

\section{References:-}

1. Shewach DS, Kuchta RD. Introduction to cancer chemotherapeutics. Chem Rev. 2009;109(7):2859-61.

2. Torre LA, Bray F, Siegel RL, Ferlay J, Lortet-Tieulent J, Jemal A. Global cancer statistics, 2012. CA Cancer J Clin. 2015;65(2):87-108.

3. Purkayastha A, Sharma N, Pathak A, Kapur BN, Dutta V. An extremely rare case of metastatic retinoblastoma of parotids presenting as a massive swelling in a child. TranslPediatr. 2016;5(2):90-4.

4. Lohmann DR, Gallie BL. Retinoblastoma [Internet]. 2015 [cited 2016 Sep 10]. Available from: http://www.ncbi.nlm.nih.gov/books/NBK1452/.

5. de Graaf P, Goricke S, Rodjan F, Galluzzi P, Maeder P, Castelijns JA, et al. Guidelines for imaging retinoblastoma: imaging principles and MRI standardization. PediatrRadiol. 2012;42(1):2.

6. Dimaras H, Corson TW, Cobrinik D, White A, Zhao J, Munier F, et al. Retinoblastoma. Nat Rev Dis Primers. 2015;1:15021.

7. Parulekar MV. Retinoblastoma - current treatment and future direction. Early Hum Dev. 2010;86(10):619-25.

8. Aerts I, Rouic LLL, Gauthier-Villars M, Brisse H, DozFDesjardins L. Retinoblastoma. Orphanet J Rare Dis. 2006;1:31.

9. Laurie NA, Donovan SL, Shih CS, Zhang J, Mills N, Fuller C, et al. Inactivation of the p53 pathway in retinoblastoma. Naturr. 444,61-6.

10. Nork TM, Poulsen GL, Millecchia LL, Jantz RG, Nickells RW. p53 regulates apoptosis in human retinoblastoma. Arch Ophthalmol.115,213-9.

11. Straface G, Selmin A, Zanardo V, De Santis M, Ercoli A, Scambia G. Herpes simplex virus infection in pregnancy. Infect Dis Obstet Gynecol.2012;385697.

12. Gupta R, Warren T, Wald A. Genital herpes. Lancet. 2007;370(9605):2127-37.

13. Nguyen ML, Kraft RM, Aubert M, Goodwin E, DiMaio D, Blaho JA. p53 and hTERT determine sensitivity to viral apoptosis. J Virol. 2007;81(23):12985-95.

14. Shen Y, Nemunaitis J. Herpes simplex virus 1 (HSV-1) for cancer treatment. Cancer Gene Ther. 2006;13(11):975-92.

15. Hume AJ, Kalejta RF. Regulation of the retinoblastoma proteins by the human herpesviruses. Cell Div,2009;4(1):1.

16. [Internet]. Abcam.com. 2016 [cited 2016 Sep 10]. Available from: http://www.abcam.com/ [used as a protocol reference in the lab]. 